\title{
PENGEMBANGAN PERANGKAT PEMBELAJARAN MODEL SIKLUS BELAJAR 5E PADA MATERI HUKUM DASAR KIMIA DALAM MENINGKATKAN HASIL BELAJAR MAHASISWA
}

\author{
Rody Putra Sartika ${ }^{1)}$, Lukman Hadi ${ }^{2}$ \\ Prodi Pendidikan Kimia FKIP UNTAN ${ }^{1), 2)}$ \\ Jalan Prof. H. Hadari Nawawi Pontianak \\ rodyputrasartika@gmail.com
}

\begin{abstract}
The aim of this study was to describe the student' understanding of law of Fundamental chemistry concept after learning using tools developed through $5 E$ learning cycle model. Designing of learning tools adopted Dick and Carey model. Learning tools was tested on students PGMIPAU FKIP Untan first half of 2014. This type of study was Research and Development. Instruments in this study were the achievement test, observation sheets of lesson plan implementation and observation sheets of barriers in learning. Data were analyzed using qualitative descriptive analysis. The findings of the study were: tools developed had feasible validity, implementation of lesson plan was very good, and students' understanding of law of fundamental chemistry concepts was improved that can be seen from the normalized gain scores. It was concluded that student' learning outcomes after implementing $5 E$ learning cycle model on the law of fundamental chemistry has increased.
\end{abstract}

Key words :5E learning cycle model, law of fundamental chemistry.

Kimia sebagai bagian
sains seharusnya juga
memberikan suatu strategi
menarik dan menyenangkan di da
proses pembelajarannya sehi
dapat mencapai tujuan
diharapkan. Menurut Depdik
(2003), Mempelajari ilmu kimia
"Midak hanya bertujuan
menemukan zat-zat baru
yang langsung bermanfaat
bagi kesejahteraan umat
manusia belaka, akan
tetapi ilmu kimia dapat
pula memenuhi keinginan
seseorang berbagai
memahami bang
peristiwa alam yanat
ditemukan
dalam
kehidupan sehari-hari, mengetahui hakikat serta perubahannya,
menanamkan metode
ilmiah, mengembangkan
kemampuan dalam
mengajukan gagasan dan
memupuk ketekunan serta
ketelitian kerja."

Selama ini mata pelajaran kimia merupakan salah satu mata pelajaran yang sulit bagi peserta didik.Menurut Sirhan (2007) karena topik kimia umumnya terkait dengan struktur dari suatu materi, hal ini membuat kimia menjadi pelajaran yang sulit bagi banyak peserta didik.Disamping itu, kimia merupakan mata pelajaran yang 
banyak mempelajari konsep abstrak (Adaminata \& Marsih, 2011), yang memerlukan komitmen waktu dan usaha dari peserta didik (Wu \& Foos, 2010).

Keabstrakan pada mata pelajaran kimia semakin kompleks dengan dengan adanya konsep yang berlawanan dengan intuisi, sehingga menyebabkan banyak kesulitan bahkan miskonsepsi pada mahasiswa. Kesulitan ini salah satunya dapat ditemukan pada materi hukum dasar kimia, dimana selama ini mahasiswa hanya memahami materi ini berdasarkan fenomena yang tampak saja. Sebagai contoh dapat ditemukan pada mata kuliah praktikum kimia dasar I dalam membuktian hukum kekekalan massa, mahasiswa mengamati massa zat sebelum dan setelah bereaksi adalah sama untuk reaksi yang tidak menghasilkan gas atau dilakukan pada wadah tertutup. Pada reaksi yang menghasilkan gas dan dilakukan pada wadah terbuka akan diperoleh massa zat sebelum dan setelah reaksi yang berbeda. Perbedaan massa zat sebelum dan setelah reaksi tersebut membuat mahasiswa berasumsi bahwa hukum kekekalan massa tidak terjadi pada reaksi tersebut, padahal apabila gas yang dihasilkan ditampung di dalam wadah dan di timbang massanya, maka akan memperoleh massa zat sebelum dan setelah reaksi yang sama.

Berdasarkan penjelasan di atas menunjukkan bahwa sebagian besar pemahaman konsep mahasiswa pada materi hukum dasar kimia khususnya pada hukum kekekalan massa seperti contoh di atas masih belum utuh, padahal materi ini merupakan materi prasyarat yang harus dikuasai mahasiswa untuk memahami materi kimia selanjutnya, seperti konsep mol dan larutan. Pembelajaran kimia diharapkan mampu memberikan pemahaman konsep yang utuh kepada mahasiswa salah satunya melalui pendekatan konstruktivis. Menurut Prawiradilaga (2009)konstruktivisme menyiapkan peserta didik untuk membentuk pemahaman dan pola pikir tersendiri. Pendekatan konstruktivis berpijak pada prinsip fundamental yang menganggap apa yang sudah diketahui peserta didik menjadi faktor utama dalam menentukan hasil dari pembelajaran dan menyediakan kesempatan kepada peserta didik untuk mengembangkan pemahaman baru dengan guru bertindak sebagai fasilitator pembelajaran daripada sebagai penyampai pengetahuan (Ausubel, 1968 dalam Gilbert \& Treagust, 2009). Pada pertemuan konstruktivis yang khas, peserta didik bekerja pada masalah dan campur tangan guru hanya diperlukan untuk membimbing peserta didik ke arah yang sesuai (Cooperstein \& Kocevar Weidinger, 2004).

perlu $\begin{gathered}\text { Pembelajaran kimia } \\ \text { dibenahi }\end{gathered}$ agar $\begin{array}{r}\text { dapat } \\ \text { dana }\end{array}$ memudahkan mahasiswa memahami materi dan mencapai tujuan yang diharapkan satu diantara adalah perbaikan kualitas perangkat pembelajaran. Perangkat pembelajaran yang tersedia pada saat ini masih cenderung menempatkan pendidik sebagai sumber pengetahuan dan pembelajaran. Pergeseran paradigma yang terjadi pada abad 21 dari penggunaan pendekatan behavioristik menjadi pendekatan konstruktivis di dalam pembelajaran. Menurut Talib, Matthews, \& 
Secombe (2005) banyak peneliti percaya konstruktivisme dapat memfasilitasi strategi pengajaran baru di bidang pendidikan sains, untuk mengatasi kritikan dari pendekatan konvensional, yang lebih mengandalkan hafalan dan pembacaan fakta-fakta ilmiah daripada memahami fakta-fakta.

Menurut Hamzah, B Uno (2008) untuk memperbaiki kualitas pembelajaran perlu diawali dengan perencanaan pembelajaran yang diwujudkan dengan adanya desain pembelajaran. Desain sistem pembelajaran perlu diimplementasikan secara sistematik dan sistematis agar dapat memberikan dampak yang optimal terhadap proses dan program pembelajaran (Pribadi, 2009). Perbaikan kualitas perangkat pembelajaran dengan pendekatan konstruktivis menuntut mahasiswa untuk dapat mandiri dalam berpikir dan membentuk kerangka atau skemata sendiri.Beberapa strategi pembelajaran dengan pendekatan konstruktivis yang dapat digunakan di dalam pembelajaran kimia satu diantaranya adalah model siklus belajar (learning cycle/LC).

Model siklus belajar terdiri atas lima fase pembelajaran yang meliputi: Engagement, Exploration, Explanation, Elaboration, dan Evaluation(Lorsbach, 2002). Melalui siklus belajar mahasiswa dapat mengidentifikasi suatu pola keteraturan dalam fenomena yang diselidiki, kemudian memperkenalkan konsep-konsep yang ada hubungannya dengan fenomena yang diselidiki dan mendiskusikannya dalam konteks apa yang telah diamati, selanjutnya menggunakan konsepkonsep yang telah diperkenalkan pada situasi baru. Siklus belajar merupakan model pembelajaran berbasis penelitian yang dapat membantu peserta didik mengeksplorasi konsep dalam sains dan membantu pendidik saat mereka merencanakan pelajaran yang dimaksudkan untuk fasilitasi yang bermakna dan pemahaman yang mendalam mengenai konsep yang diajarkan (Duran, Duran, Haney, \& Scheuermann, 2011).

Pada penerapan di kelas, model siklus belajar dirangkai dalam lima fase kegiatan. Fase engagement dilakukan dengan membuat koneksi ke pengalaman masa lalu dan mengekspos miskonsepsi mahasiswa dan mereka harus mengurangi ketidakseimbangan kognitif yang terjadi. Fase exploration dilakukan dengan membangun pengalaman dosen dan mahasiswa yang dapat digunakan kemudian untuk memperkenalkan dan mendiskusikan konsep, proses, atau keterampilan. Lembar Kerja Mahasiswa (LKM) dapat digunakan pada fase ini untuk membantu proses awal merumuskan konsep yang memadai dan akurat. Menurut Cooperstein \& Kocevar Weidinger (2004) konsep-konsep abstrak menjadi berarti, ditransfer, dan disimpan karena mereka terikat dengan kinerja dari suatu kegiatan. Pada fase exploration dapat mengarahkan pada penemuan konsep yang diajarkan dan dapat membangun makna dari konsep tersebut.

Fase explanation dilakukan dengan meminta mahasiswa menjelaskan pengalaman eksplorasi dan pengalaman engagement mereka dengan menggunakan istilah umum. Fase elaboration dilakukan dengan melibatkan mahasiswa dalam situasi baru dan masalah yang memerlukan 
transfer penjelasan yang indentik atau mirip. Melalui pengalaman baru, mahasiswa mengembangkan pemahaman yang lebih mendalam dan lebih luas serta informasi dan keterampilan yang memadai. Fase evaluation dilakukan dengan memberikan penilaian terhadap pengetahuan, pemahaman konsep, atau kompetensi mahasiswa dalam konteks baru yang kadang-kadang mendorong mahasiswa belajar melakukan investigasi lebih lanjut, dengan cara refleksi pelaksanaan pembelajaran.

Beberapa hasil penelitian para ahli menunjukkan bahwa penggunaan siklus belajar dapat memperjelas proses berpikir peserta didik dan memperbaiki miskonsepsi mereka (Balci, Cakiroglu, \& Tekkaya, 2006). Menurut Abraham \& Renner (1986); Beeth \& Hewson (1999); Gerber, Cavallo, \& Marek (2001); McComas (1992) dalam Hanuscin \& Lee (2008) siklus belajar dapat menghasilkan prestasi yang lebih baik dalam sains, retensi konsep yang lebih baik, meningkatkan sikap terhadap sains dan pembelajaran sains, meningkatkan kemampuan penalaran, dan keterampilan proses yang unggul daripada dengan pendekatan pembelajaran tradisional. Berdasarkan penjelasan di atas, diperlukan strategi pembelajaran yang menggunakan model siklus belajar 5E dalam mengajarkan materi hukum dasar kimia untuk meningkatkan pemahaman konsep mahasiswa. Strategi tersebut dapat terencana dengan baik apabila didukung dengan perangkat pembelajaran yang terencana sebagai pedoman penyelenggaraan pembelajaran untuk mencapai tujuan yang diharapkan.
Berdasarkan penjelasan di atas, peneliti ingin melakukan penelitian tentang pengembangan perangkat pembelajaran menggunakan model siklus belajar 5E pada materi hukum dasar kimia dalam meningkatkan pemahaman konsep mahasiswa.

\section{Metode}

Penelitian ini termasuk penelitian pengembangan, karena mengembangkan perangkat pembelajaran menggunakan model siklus belajar 5E, yang meliputi: Satuan Acara Perkuliahan (SAP), lembar kerja mahasiswa (LKM) dan tes hasil belajar (THB). Kualitas dari perangkat pembelajaran yang dikembangkan dapat diketahui dari aspek kelayakan, kepraktisan dan keefektifannya. Uji coba dilakukan pada mahasiswa PGMIPAUFKIP UNTAN Tahun Ajaran 2014/2015.Pada uji coba I melibatkan 25 mahasiswa. Desain penelitian pengembangan perangkat pembelajaran menggunakan one group pretest-postest design. Model pengembangan perangkat pembelajaran yang digunakan dalam penelitan ini adalah model Dick dan Carrey yang diadaptasi dari Dick, Carey, \& Carey (2009). Langkahlangkah model Dick dan Carrey, meliputi: 1) identifikasi tujuan umum pembelajaran, 2) melaksanakan analisis pembelajaran, 3) analisis siswa dan konteks, 4) merumuskan tujuan kinerja, 5) mengembangkan instrumen penilaian, 6) mengembangkan strategi pembelajaran, 7) mengembangkan dan memilih materi pembelajaran, 8) mendesain dan melaksanakan evaluasi formatif, dan 9) merevisi bahan pembelajaran. Teknik 
pengumpulan data yang digunakan adalah pengukuran menggunakan instrumen tes hasil belajar dan observasi menggunakan instrumen lembar pengamatan keterlaksanaan pembelajaran dan lembar pengamatan hambatan di dalam pembelajaran.Teknik analisis data menggunakan analisis deskriptif kualitatif.

\section{Hasil dan Pembahasan}

1. Kelayakan perangkat pembelajaran yang dikembangkan.

Kelayakan perangkat pembelajaran yang dikembangkan diperoleh dari hasil validasi oleh tiga orang validator. Perangkat pembelajaran yang divalidasi meliputi: Satuan Acara Perkuliahan (SAP), Lembar Kerja Mahasiswa (LKM), dan Tes Hasil Belajar (THB). Penilaian kelayakan SAP pada setiap aspek memenuhi dua kategori, yaitu layak dan sangat layak. Saran dari validator dan upaya perbaikan SAP yang dilakukan peneliti dapat dilihat pada Tabel 1.

Tabel 1.Saran dan upaya perbaikan pada validasi SAP.

\begin{tabular}{|c|c|c|}
\hline No. & Saran & Upaya perbaikan \\
\hline 1. & $\begin{array}{l}\text { Penulisan indikator } \\
\text { dan tujuan } \\
\text { pembelajaran } \\
\text { sebaiknya dipisah. }\end{array}$ & $\begin{array}{lr}\text { Penulisan indikator } \\
\text { dan } & \text { tujuan } \\
\text { pembelajaran dipisah. }\end{array}$ \\
\hline 2. & $\begin{array}{lr}\text { Alokasi } & \text { waktu } \\
\text { sebaiknya dirincikan } \\
\text { untuk setiap fase } \\
\text { pada } & \text { model } \\
\text { pembelajaran } & \text { siklus } \\
\text { belajar } & \\
\end{array}$ & $\begin{array}{l}\text { Alokasi waktu dirinci } \\
\text { pada setiap fase } \\
\text { model pembelajaran } \\
\text { siklus belajar. }\end{array}$ \\
\hline 3. & \begin{tabular}{lr}
\multicolumn{2}{l}{ Pada penilaian aspek } \\
afektif, keterampilan \\
sosial rebaiknya \\
diganti r dengan \\
keterampilan \\
komunikasi.
\end{tabular} & $\begin{array}{lr}\text { Keterampilan } & \text { sosial } \\
\text { pada aspek } & \text { afektif } \\
\text { diganti } & \text { dengan } \\
\text { keterampilan } & \\
\text { komunikasi. } & \end{array}$ \\
\hline
\end{tabular}

Penilaian kelayakan LKM pada setiap aspek memenuhi kategori layak dan sangat layak. Saran dari validator dan upaya perbaikan LKM yang dilakukan peneliti dapat dilihat pada Tabel 2 .

Tabel 2.Saran dan upaya perbaikan pada validasi LKM.

\begin{tabular}{clr}
\hline No. & \multicolumn{1}{c}{ Saran } & \multicolumn{1}{c}{$\begin{array}{c}\text { Upaya } \\
\text { perbaikan }\end{array}$} \\
\hline 1. & $\begin{array}{l}\text { Lembar kerja } \\
\text { mahasiswa }\end{array}$ & $\begin{array}{l}\text { LKM dilengkapi } \\
\text { dengan teori dan } \\
\text { pertanyaan. }\end{array}$ \\
& $\begin{array}{l}\text { (LKM) } \\
\text { sebaiknya di } \\
\text { lengkapi dengan } \\
\text { teori dan } \\
\text { pertanyaan. }\end{array}$ \\
\hline
\end{tabular}

Penilaian kelayakan THB pada setiap aspek memenuhi kategori layak dan sangat layak. Saran dari validator dan upaya perbaikan THB yang dilakukan peneliti untuk memperbaiki hasil pengembangan dapat dilihat pada Tabel 3.

Tabel 3.Saran dan upaya perbaikan pada validasi THB.

\begin{tabular}{|c|c|c|}
\hline No & Saran & Upaya perbaikan \\
\hline 1. & $\begin{array}{l}\text { Kalimat pada soal } \\
\text { nomor } 3 \text { dan } 5 \\
\text { sebaiknya } \\
\text { menggunakan kata } \\
\text { kerja operasional. }\end{array}$ & $\begin{array}{l}\text { Kalimat pada soal } \\
\text { nomor } 3 \text { dan } 5 \\
\text { menggunakan kata } \\
\text { kerja operasional. }\end{array}$ \\
\hline 2. & $\begin{array}{lr}\text { Soal } & \text { seharusnya } \\
\text { dikaitkan } & \text { dengan } \\
\text { kehidupan } & \text { sehari- } \\
\text { hari. } & \end{array}$ & $\begin{array}{l}\text { Soal dikaitkan } \\
\text { dengan kehidupan } \\
\text { sehari-hari } \\
\text { menggunakan data } \\
\text { hasil pengamatan. }\end{array}$ \\
\hline
\end{tabular}

\section{Berdasarkan validasi yang} telah dilakukan, terdapat beberapa saran dari validator (dapat dilihat pada Tabel 1, 2, dan 3) yang digunakan oleh peneliti untuk memperbaiki perangkat pembelajaran yang telah dikembangkan, sehingga 
perangkat pembelajaran yang digunakan menjadi lebih baik dari sebelumnya. Menurut Arikunto (1997) validitas adalah suatu ukuran yang menunjukkan tingkat-tingkat kevalidan atau kesahihan sesuatu instrumen.

\section{Kepraktisan perangkat}

pembelajaran yang dikembangkan.

Kepraktisan dari perangkat pembelajaran yang dikembangkan diperoleh dari hasil keterlaksanaan pembelajaran dengan perangkat pembelajaran menggunakan model siklus belajar $5 \mathrm{E}$ pada materi hukum dasar kimia diamati oleh lima orang observer yang telah dilatih sebelumnya dengan menggunakan lembar pengamatan keterlaksanaan pembelajaran.Hasil reliabilitas instrumen lembar keterlaksanaan pembelajaran diperoleh $r_{11}=0,350$, yang berarti bahwa instrumen yang digunakan dapat dipercaya untuk digunakan sebagai alat pengumpul data.Keterlaksanaan pembelajaran pada setiap tahapan pembelajaran memenuhi kategori baik dan sangat baik.

Aspek yang diamati pada keterlaksanaan pembelajaran terbagi ke dalam dua bagian yaitu pengamatan kegiatan belajar mengajar (KBM) dan suasana kelas.Rata-rata hasil pengamatan keterlaksanaan pembelajaran secara keseluruhan pada setiap kelas termasuk ke dalam kategori baik dan sangat baik.Pengamatan kegiatan belajar mengajar (KBM) pada tahap pendahuluan merupakan fase pertama dalam siklus belajar (engagement), dimana dosen menyajikan fenomena dan mengajukan pertanyaan atas fenomena yang telah diberikan.Dosen secara aktif memotivasi mahasiswa untuk fokus dalam kegiatan belajar mengajar, yang dapat terlihat dari hasil pengamatan pada antusias dosen dan mahasiswa di dalam kelas yang menunjukkan rata-rata keterlaksanaan pembelajaran dengan kategori sangat baik.Kegiatan selanjutnya pada tahap pendahuluan dosen menyampaikan tujuan pembelajaran.Rata-rata hasil pengamatan keterlaksanaan tahap pendahuluan termasuk dalam kategori baik. Dosen tidak hanya menyampaikan tujuan pembelajaran secara lisan, tetapi memberikan penekanan pada tujuan pembelajaran tersebut, sehingga mahasiswa diharapkan dapat tetap fokus pada tujuan pembelajaran yang diharapkan. Pada tahap kegiatan inti terdapat di dalamnya empat fase model siklus belajar yaitu: fase exploration, fase explanation, fase elaboration dan fase evaluation. Fase exploration dimulai dengan membentuk kelompok belajar mahasiswa yang heterogen, membagikan LKM pada setiap kelompok mahasiswa masing-masing 2 LKM dan menugaskan serta membimbing mahasiswa untuk melaksanakan praktikum sesuai dengan LKM, kemudian menjawab pertanyaan-pertanyaan di dalamnya. Rata-rata hasil pengamatan keterlaksanaan pembelajaran secara keseluruhan yang dilakukan oleh observer pada fase ini termasuk dalam kategori sangat baik. Pada fase ini dosen perlu memberikan perhatian lebih dalam membimbing mahasiswa melakukan praktikum khususnya dalam mengisi data hasil pengamatan. Hal ini disebabkan karena beberapa mahasiswa masih tampak kebingungan pada kegiatan tersebut. 
Menurut Wass, Harland, \& Mercer (2011) jika pendidik tidak segera memberikan scaffolding kepada peserta didik maka akan menyebabkan kecenderungan melakukan kegiatan di luar pembelajaran. Oleh sebab itu, dosen perlu membimbing mahasiswa ketika mulai merekonstruksi penjelasan mereka pada kegiatan tersebut.Melalui bimbingan yang diberikan dosen kepada mahasiswa dapat membuat mereka mencapai zone of proximal development (ZPD).Menurut Slavin (2011) tugastugas dalam zona perkembangan proksimal adalah sesuatu yang masih belum dapat dikerjakan seorang anak sendirian tetapi benar-benar dapat dikerjakan dengan bantuan teman yang lebih kompeten atau orang dewasa.

Fase explanation, dosen membimbing diskusi hasil praktikum yang telah dilakukan melalui diskusi kelompok dan diskusi kelas.Dosen berusaha mengembangkan penjelasan mahasiswa dengan menghubungkan penjelasan tersebut dengan pengalaman yang telah diperoleh mahasiswa pada fase engagement dan fase exploration. Menurut Byber, Taylor, Gardner, Pamela Van Scotter, \& Landes (2006) pendidik mempunyai berbagai teknik dan strategi yang mereka miliki untuk memperoleh dan mengembangkan penjelasan peserta didik, biasanya menggunakan penjelasan verbal, tetapi ada banyak strategi lainnya, seperti video, film, dan kursus pendidikan. Penjelasan yang diberikan dosen dapat membimbing mahasiswa menuju pemahaman yang lebih dalam, yang merupakan bagian penting dari fase ini.
Fase elaboration, dosen membagikan LKM lanjutan, selanjutnya menugaskan mahasiswa melaksanakan praktikum lanjutan dengan menggunakan LKM lanjutan serta menjawab pertanyaanpertanyaan di dalam LKM tersebut.Fase evaluation, dosen meminta mahasiswa mengisi latihan soal yang terdapat di dalam LKM.Rata-rata hasil pengamatan keterlaksanaan pembelajaran secara keseluruhan yang dilakukan oleh observer pada keempat fase termasuk dalam kategori sangat baik.Berdasarkan suasana kelas selama KBM berjalan sesuai dengan tujuan pembelajaran yang diharapkan, demikian juga dengan sintaks yang dilakukan telah sesuai dengan model pembelajaran yang digunakan. Disamping itu, selama KBM cenderung berpusat pada mahasiswa, hal ini disebabkan model siklus belajar merupakan model pembelajaran yang berpusat pada mahasiswa, dimana fase-fase di dalam pembelajarannya diorganisir sedemikian rupa sehingga mahasiswa dapat menguasai kompetensikompetensi yang harus dicapai dengan jalan berperan aktif.

3. Keefektifan perangkat pembelajaran yang dikembangkan.

Keefektifan perangkat pembelajaran yang dikembangakn diperoleh dari hasil belajar mahasiswa diperoleh dari tes hasil belajar yang dilakukan dua kali, yaitu tes awal (pretest) yang diberikan sebelum pembelajaran dan tes akhir (posttest) yang diberikan setelah pembelajaran. Hasil reabilitas instrumen tes hasil belajar diperoleh $\mathrm{r}_{11}=0,212$ yang berarti bahwa instrumen yang digunakan dapat 
dipercaya untuk dapat digunakan sebagai alat pengumpul data. Indeks sensitivitas efek pembelajaran yang diperoleh mulai dari 0 hingga 0,48 . Nilai sensitivitas pada item soal 2 memiliki sensitivitas di atas 0,3. Rendahnya nilai sensitivitas dari item soal lainnya disebabkan hanya beberapa mahasiswa yang dapat menjawab item soal tersebut dengan benar. klasikal diukur berdasarkan hasil belajar mahasiswa melalui pemberian tes hasil belajar (pretest dan posttest).Pada tes awal (pretest) semua mahasiswa memiliki nilai di bawah kriteria ketuntasan minimal (KKM) yang ditetapkan untuk materi hukum dasar kimia sebesar 75 .

Tabel 4. Rata-rata ketuntasan indikator pada pretest.
Ketuntasan individual dan

awal (pretest) untuk mengetahui kemampuan awal mahasiswa sebelum diberikan perlakuan dan tes akhir (posttest) untuk mengetahui pemahaman konsep mahasiswa setelah diberikan perlakuan dengan menggunakan model siklus belajar pada materi hukum dasar kimia. Hasil reabilitas instrumen tes hasil belajar menunjukkan bahwa instrumen yang digunakan dapat dipercaya sebagai alat pengumpul data dengan kategori rendah. Indeks sensitivitas efek pembelajaran yang diperoleh mulai dari 0 hingga 0,48 , dalam hal ini nilai-nilai positif yang lebih besar akan menunjukkan item dengan sensitivitas yang lebih besar terhadap efek dari pembelajaran. Pada item soal 1, 3, 4, 5 dan 6 memiliki sensitivitas di bawah 0,3 , rendahnya indeks sentivitas yang diperoleh ketiga item soal tersebut disebabkan karena pada posttest

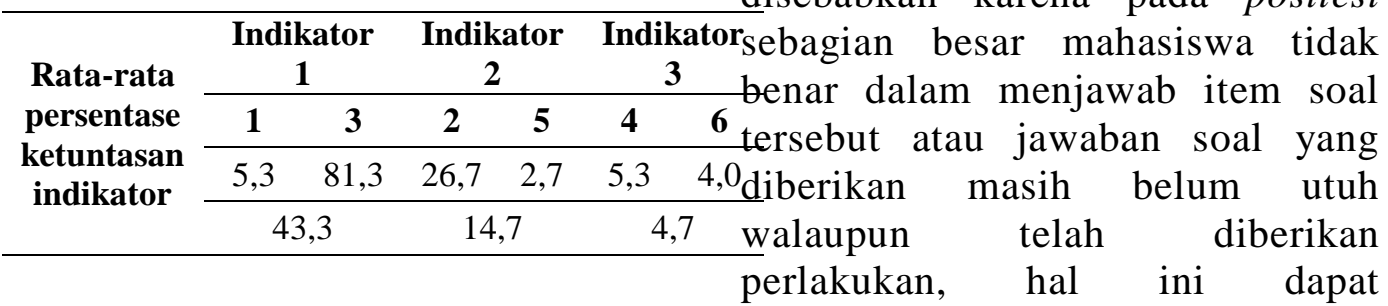

Pada tes akhir semua mahasiswa masih belum memenuhi nilai KKM sama dengan 75 .

Tabel 5.Rata-rata ketuntasa indikator pada posttest.

\section{disebabkan karena dalam perolehan} konsep mahasiswa belum seutuhnya dapat melakukan proses asimilasi dan akomodasi dari konsep yang dipelajari, sehingga penguasaan konsep masih belum luas dan mendalam.

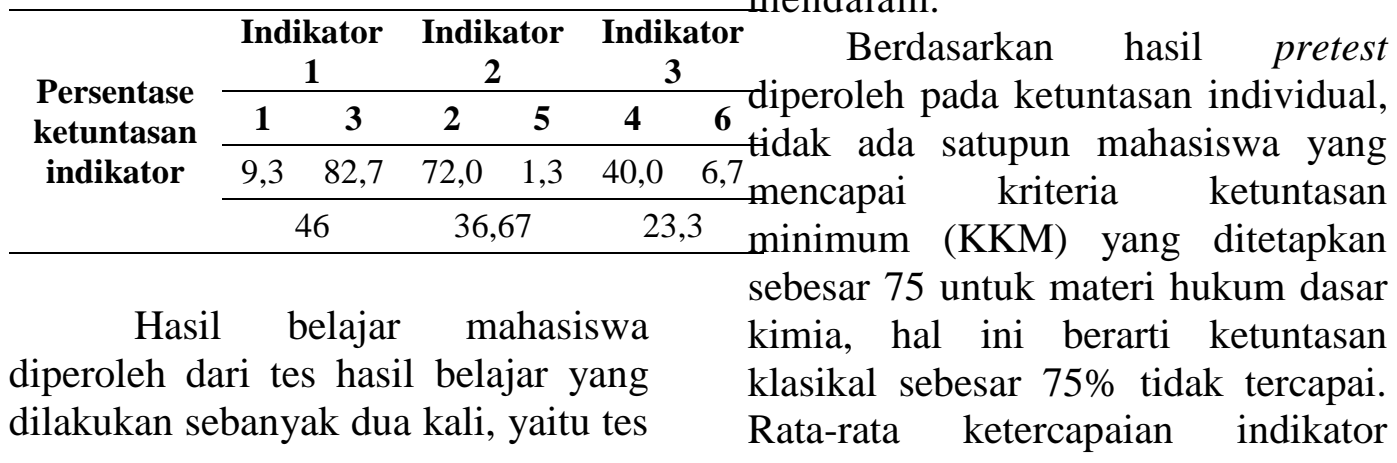


pembelajaran < 75\% kecuali pada item soal nomor 3 (indikator 2). Tidak tercapainya ketuntasan individual maupun rendahnya ratarata ketercapaian indikator disebabkan karena dalam menjawab soal pretest, mahasiswa hanya menggunakan skema awal yang terdapat dipikirannya dengan didasarkan pada hasil kesimpulan dari pemikiran yang ada pada saat mereka menjawab soal tersebut.

Mahasiswa dalam menjawab soal pretest hanya menggunakan konsepsi awal (prakonsepsi) yang dimilikinya untuk materi hukum dasar kimia berdasarkan pada pengetahuan yang pernah diperolehnya semasa SMA atau berdasarkan intuisi maupun pengalaman sehari-hari. Menurut Lucariello (2013) peserta didik tidak datang ke sekolah sebagai papan tulis kosong untuk diisi dengan pengajaran, sebaliknya, mereka datang ke sekolah dengan pengetahuan yang cukup, beberapa benar dan beberapa tidak, baik pengetahuan didasarkan pada intuisi, pengalaman sehari-hari, serta apa yang sudah diajarkan pada mereka dalam setting lainnya. Sebagian dari pemahaman tersebut sesuai dengan pemahaman yang dimiliki dan diyakini kebenarannya oleh para ilmuwan (sesuai dengan konsep ilmiah), akan tetapi banyak juga diantara pemahaman yang dimiliki seseorang sama sekali berbeda dengan konsep ilmiah yang diakui kebenarannya (Ibrahim, 2012).

Hasil posttest diperolehsemua mahasiswa belum mencapai kriteria ketuntasan minimum (KKM) yang ditetapkan sebesar 75 untuk materi hukum dasar kimia, sehingga ketuntasan secara klasikal belum
tercapai.Berdasarkan

rata-rata ketercapaian indikator $<75 \%$ kecuali pada item soal nomor 3 (indikator 2). Tingginya rata-rata ketercapaian item soal nomor 3 pada indikator 2 dapat disebabkan karena mahasiswa telah memperoleh keterampilan prasyarat (subordinate skills) yang diperoleh dari materi sebelumnya, yaitu materi persamaan reaksi. Keterampilan prasyarat yang diperoleh mahasiswa pada materi sebelumnya telah menjadi skema untuk memahami pengalaman baru berdasarkan skema yang telah ada melalui proses asimilasi dan akomodasi. Menurut Arends (2008) asimilasi terjadi apabila individu mempaskan insformasi baru dengan skemata yang sudah ada, sedangkan akomodasi terjadi apabila individu mengubah skemata yang sudah ada untuk merespon ide atau situasi baru.

$\begin{array}{lr}\text { Rendahnya } & \text { rata-rata } \\ \text { ketercapaian indikator dapat }\end{array}$ disebabkan karena materi pada indikator tersebut bersifat abstrak dan merupakan implementasi di dalam kehidupan sehari-hari berdasarkan data-data pada kegiatan praktikum, sehingga menjadikannya sebagai konsep yang kompleks yang memerlukan pemahaman konsep mahasiswa yang utuh.Menurut Silaholo (2008) suatu konsep kompleks hanya dapat dikuasai dengan baik dan benar bila konsepkonsep yang mendasari telah dikuasai dengan baik dan benar pula.Menurut Dahar (1996) tingkat-tingkat pencapaian konsep yang diharapkan tercermin dari tujuan-tujuan yang dirumuskan bagi peserta didik.Tidak tercapainya ketuntasan individual dari mahasiswa dapat disebabkan karena terdapat beberapa indikator 
pembelajaran yang belum tercapai, di mana dapat terjadi kesalahan pemahaman terhadap suatu konsep oleh mahasiswa.

Menurut Ibrahim (2012)

kesalahan konsep dapat terjadi karena: 1) penguasaan konsep oleh peserta didik belum lengkap, sederhana dan berbeda; 2) karena ketidakmampuan peserta didik membedakan atribut (ciri penentu) dari sejumlah ciri umum yang dimiliki oleh sebuah konsep; 3) miskonsepsi terjadi karena peserta didik tidak menguasai konsep prasyarat dari suatu konsep tertentu; 4) jumlah atribut yang relevan dan tidak relevan, yang digunakan ketika mengajar konsep juga mempengaruhi tingkat kesulitan memperoleh/memahami suatu konsep; 5) istilah sehari-hari yang dijumpai pertama kali oleh peserta didik di dalam bahasa Ibunya, juga mempengaruhi kesalahan konsep; 6) beberapa sumber belajar yang digunakan peserta didik untuk belajar konsep juga memiliki kontribusi dalam meningkatkan miskonsepsinya.

4. Hambatan-hambatan di dalam pembelajaran.

Secara umum pelaksanaan pembelajaran dengan menggunakan model siklus belajar 5E pada materi hukum dasar kimia berlangsung dengan baik, akan tetapi terdapat hambatan yang ditemukan di dalam pembelajaran sehingga perlu solusi yang dapat dilihat pada Tabel 6 .

Tabel 6. Hambatan di dalam pembelajaran dan solusi.

\begin{tabular}{cll}
\hline No. & $\begin{array}{c}\text { Hambatan yang } \\
\text { ditemukan }\end{array}$ & $\begin{array}{c}\text { Solusi yang } \\
\text { ditawarkan }\end{array}$ \\
\hline 1 & $\begin{array}{l}\text { Memerlukan } \\
\text { waktu yang lebih }\end{array}$ & $\begin{array}{l}\text { Perlunya } \\
\text { bimbingan yang }\end{array}$ \\
\hline
\end{tabular}

\begin{tabular}{|c|c|c|}
\hline No. & $\begin{array}{c}\text { Hambatan yang } \\
\text { ditemukan }\end{array}$ & $\begin{array}{l}\text { Solusi yang } \\
\text { ditawarkan }\end{array}$ \\
\hline & $\begin{array}{l}\text { lama untuk } \\
\text { membimbing } \\
\text { mahasiswa pada } \\
\text { fase exploration } \\
\text { dan fase } \\
\text { elaboration, } \\
\text { karena } \\
\text { mahasiswa baru } \\
\text { masihbelum } \\
\text { terbiasa } \\
\text { melakukan } \\
\text { praktikum dan } \\
\text { mengisi lembar } \\
\text { kerja mahasiswa } \\
\text { (LKM) secara } \\
\text { mandiri. }\end{array}$ & $\begin{array}{l}\text { lebih intensif } \\
\text { yang diberikan } \\
\text { dosen kepada } \\
\text { mahasiswa pada } \\
\text { fase exploration } \\
\text { dan fase } \\
\text { elaboration, } \\
\text { sehingga waktu } \\
\text { diperlukan } \\
\text { kedua fase } \\
\text { tersebut dapat } \\
\text { dimanfaatkan } \\
\text { secara efektif. }\end{array}$ \\
\hline
\end{tabular}

\section{Simpulan dan Saran}

Berdasarkan hasil penelitian dan pembahasan serta temuan-temuan di dalam penelitian, dapat disimpulkan bahwa pemahaman konsep siswa setelah pembelajaran menggunakan perangkat yang dikembangkan melalui model siklus belajar 5E pada materi hukum dasar kimia mengalami peningkatan. Berdasarkan hambatan yang ditemukan di dalam penelitian ini, diberikan saran sebagai solusi alternatif yaitu: memberikan lebih banyak perhatian dan bimbingan kepada mahasiswa pada fase exploration dan fase elaboration, sehingga waktu diperlukan kedua fase tersebut dapat dimanfaatkan secara efektif. Pada kedua fase tersebut memerlukan waktu yang lebih lama untuk mahasiswa baru melakukan praktikum sesuai dengan lembar kerja mahasiswa (LKM) dan secara aktif membangun konsep secara mandiri (fase exploration) serta mengembangkan pemahaman konsep yang lebih dalam dan luas dalam situasi yang sama tetapi baru (fase elaboration). 


\section{Daftar Pustaka}

Adaminata, M. A., \& Marsih, I. N. (2011, September 23). Analisis Kesalahan Konsep Siswa SMA pada Pokok Bahasan Kesetimbangan Kimia. Dipetik Januari 27, 2013, dari google.com: http://portal.fi.itb.ac.id/cps/

Arends, R. L. (2008). Learning To Teach Edisi Ketujuh. Yokyakarta: Pustaka Pelajar.

Arikunto, S. (1997). Prosedur Penelitian Suatu Pendekatan Praktek. Jakarta: PT. Rineka Cipta.

Balci, S., Cakiroglu, J., \& Tekkaya, C. (2006). Enggagement, Exploration, Explanation, Extension, and Evaluation (5E) Learning Cycle and Conceptual Change Text as Learning Tools. Biochemistry and Molecular Biology Education, Vol. 34, No. 3, 199-203.

Byber, R. W., Taylor, J. A., Gardner, A., Pamela Van Scotter, J. C., \& Landes, N. (2006). The BSCS 5E Instructional Model: Origins and Effectiveness. Colorado Springs: BSCS.

Cooperstein, S. E., \& Kocevar Weidinger, E. (2004). Beyond Active Learning: a Constructivist Approach to
Learning. Emerald Group Publishing Limited, 141-148.

Dahar, R. W. (1996). Teori-Teori Belajar. Jakarta: Erlangga.

Depdiknas. (2003). Kurikulum 2004 Standar Kompetensi Mata Pelajaran Kimia SMA dan MA. Jakarta: Departemen Pendidikan Nasional.

Dick, W., Carey, L., \& Carey, J. O. (2009). The Systematic Design of Introduction 7th ed. New Jersey: Pearson Education.

Duran, E., Duran, L., Haney, J., \& Scheuermann, A. (2011). A Learning Cycle for All Student. Ohio: Sci Links.

Gilbert, J. K., \& Treagust, D. (2009). Multiple Refresentation in Chemical Education. Australia: Springer.

Hamzah B, U. (2008). Model Pembelajaran Menciptakan Proses Belajar Mengajar yang Kreatif dan Efektif. Jakarta: PT. Bumi Aksara.

Hanuscin, D. L., \& Lee, M. H. (2008). Using the Learning Cycle as a Model for Teaching the Learning Cycle to Preserve Elemtary Teacher. Journal of Elementary Science Education, Vol. 20. No. 2, 5166.

Ibrahim, M. (2012). Konsep, Miskonsepsi dan Cara 
Pembelajarannya. Surabaya: Unesa University Press.

Lucariello, J. (2013). How Do My Students Think: Diagnosing Student Thinking (Understanding misperceptions is key early step). Retrieved Mei 23, 2012, from American Psycological Association:

http://www.apa.org/ education/k12/studentthinking.aspx ?item $=1$

Lorsbach, A. (2002). The Learning Cycle as A Tool for Planning Science Instruction. Dipetik Desember 10, 2002, dari http://www.coe.ilstu.edu/scien ceed/lorsbach/257lrcy.html.

Prawiradilaga, D. S. (2009). Prinsip Disain Pembelajaran. Jakarta : Kencana.

Pribadi, B. A. (2009). Model Desain Sistem Pembelajaran. Jakarta: PT. Dian Rakyat.

Sihaloho, M. (2008). Analisis Pemahaman Konsep Pergeseran Kesetimbangan Kimia pada Tingkat Makroskopis dan Mikroskopis siswa di SMA Negeri Gorontalo. Retrieved Oktober 14, 2012, from journal.ung.ac.id/ filejurnal/.../MSVol5No2_06.p df: www.google.com.

Sirhan, G. (2007). Learning Difficulties in Chemistry: An Overview . Journal of Turkish Science Education, 2-20.

Slavin, R. E. (2011). Psikologi Pendidikan Teori dan Praktik Edisi Kesembilan. Jakarta: PT Indeks.

Talib, O., Matthews, R., \& Secombe, M. (t.thn.). Constructivist Animation: A Promosing Alternative Tool in Bridging Theory - Practice Gap in Science Education. Dipetik Juni 4, 2013, dari http://www.recsam.edu.my/co smed/cosmed05/AbstractsFull Papers2005/files\%5Csubthem e3\%5COT.pdf:

http://www.google.com

Wass, R., Harland, T., \& Mercer, A. (2011). Scaffolding Critical Thinking in The Zone of Proximal Development. Higher Education Research \& Development Vol. 30, No. 3, 317-328.

Wu, C., \& Foos, J. (2010). Making Chemistry Fun to Learn . Literacy Information and Computer Education Journal (LICEJ), 3-7. 